\title{
Germination and soil seed bank traits of Podocarpus angustifolius (Podocarpaceae): an endemic tree species from Cuban rain forests
}

\author{
Pablo Ferrandis ${ }^{1}$, Marta Bonilla ${ }^{2} \&$ Licet del Carmen Osorio ${ }^{3}$ \\ 1. Grupo de Biología de la Conservación de Plantas, Instituto Botánico de la Universidad de Castilla La Mancha, Jardín \\ Botánico de Castilla-La Mancha, Campus Universitario s/n, Albacete 02071, España; pablo.ferrandis@uclm.es \\ 2. Facultad de Forestal y Agronomía, Universidad de Pinar del Río, C/ Martí 270 Final, Pinar del Río, Cuba; \\ mbon@af.upr.edu.cu \\ 3. Estación Territorial de Protección de Plantas, Sancti Spiritus, Cuba.
}

Received 18-VIII-2010. C Corrected 15-XII-2010. Accepted 20-I-2011.

\begin{abstract}
Podocarpus angustifolius is an endangered recalcitrant-seeded small tree, endemic to mountain rain forests in the central and Pinar del Río regions in Cuba. In this study, the germination patterns of P. angustifolius seeds were evaluated and the nature of the soil seed bank was determined. Using a weighted two-factor design, we analyzed the combined germination response to seed source (i.e. freshly matured seeds directly collected from trees versus seeds extracted from soil samples) and pretreatment (i.e. seed water-immersion for $48 \mathrm{~h}$ at room temperature). Germination was delayed for four weeks $(\approx 30$ days) in all cases, regardless of both factors analyzed. Moreover, nine additional days were necessary to achieve high germination values (in the case of fresh, pretreated seeds). These results overall may indicate the existence of a non-deep simple morphophysiological dormancy in P. angustifolius seeds. The water-immersion significantly enhanced seed germination, probably as a result of the hydration of recalcitrant seeds. Although germination of seeds extracted from soil samples was low, probably due to aging and pathogen effects throughout the time of burial, the study revealed the existence of a persistent soil seed bank (at least short-termed) of $\approx 42$ viable seeds per $\mathrm{m}^{2}$ in the upper $10 \mathrm{~cm}$ of soil. Such a record is noteworthy since references to persistent soil seed banks in recalcitrant-seeded species are scarce in the literature. The population consequences derived from the formation of persistent soil seed banks in this endangered species are discussed. Rev. Biol. Trop. 59 (3): 1061-1069. Epub 2011 September 01.
\end{abstract}

Key words: endangered plant species, morphophysiological seed dormancy, persistent soil seed bank, pregerminative treatment, recalcitrant seeds.

Seed germination and seedling establishment are the most vulnerable phases in plants life cycles (Solbrig 1980), and information about them is especially important in understanding the distribution of rare plants. Schemske et al. (1994) stressed the importance of compiling information on the stages in the reproductive cycle of endemic, rare, and threatened plant species in order to enhance our understanding of their scarcity, and to design efficient conservation measures. So, basic information on dormancy and seed germination is very important for the development of conservation strategies of plant species (Ikeda \& Itoh 2001, Navarro \& Guitian 2003, Copete et al. 2005).

In the soil, water is the key resource triggering the physiological changes driving seed germination, but temperature and sometimes light/dark conditions also can be important (Nikolaeva 1977, Baskin \& Baskin 1998). Many trees in tropical forests produce recalcitrant seeds with high water content (Chin et al. 1989), and if soil water conditions are appropriate, these seeds tend to germinate rapidly after being dispersed ( $\mathrm{Ng} \mathrm{1978).} \mathrm{Typically,} \mathrm{the}$ 
radicle emerges in a few days and germination is completed in a few weeks. Indeed, recalcitrant seeds which fail to germinate usually lose viability promptly (Whitmore 1989, Choinski 1990). However, seeds of some species are able to tolerate a certain degree of drought in the soil (i.e. semi-recalcitrant or minimally recalcitrant seeds). If water content of tissues is reduced, seeds can enter a quiescent stage until humidity in the soil recovers in the early rainy season (Vázquez et al. 1997).

Innate physiological factors and environmental conditions in the habitat determine the length that seeds remain viable in the soil prior to germination, die by physiological processes, or suffer attack from predators or pathogens (Schafer \& Chilcote 1969, Simpson et al. 1989, Baskin \& Baskin 1998). The soil seed bank is formed after viable seeds become buried in the soil and litter, or accumulate on the ground surface (Simpson et al. 1989). The number of seeds in the soil strongly depends on factors such as history, diversity, and the dynamics of the plant community covering the soil (Major \& Pyott 1966, Brown \& Oosterhuis 1981, Thompson 1992, Vázquez et al. 1997), and seeds are usually abundant in the soil under normal conditions (Simpson et al. 1989).

Soil seed banks of individual species vary significantly in length from transient to persistent types. In a transient seed bank, all seeds disappear from the soil before the next seed dispersal episode occurs, so there will be no seed reserve in the soil for a period of time. In the case of persistent seed banks, a significant fraction of seeds remains viable in the soil until the next seed dispersal event, so a plant population can always rely on a soil seed reserve (Thompson \& Grime 1979, Thompson et al. 1997). Consequently, the ecological significance of soil seeds banks is transcendental since a persistent seed bank can contribute decisively to the resilience of plant populations (Baskin \& Baskin 1978), even though no seeds are produced in a given year, and can even facilitate re-colonization after a local extinction (Milberg 1994). Obviously, such a point becomes particularly important in the case of threatened plant species.

The goals of the present study were to determine the nature of the soil seed bank and germination responses of the endangered Podocarpus angustifolius Griseb., a recalcitrantseeded tree endemic to mountain rain forests in the central and Pinar del Río regions in Cuba. We analyzed soil seed content and characterized key seed germination patterns. The general aim of the study was to enhance our knowledge of the reproductive traits of $P$. angustifolius, for which nearly no information is currently available, in order to contribute more effectively to its conservation.

\section{MATERIAL AND METHODS}

Study area and species: The study was carried out in the Ecological Reserve of Alturas de Banao, located in the Guamuhaya mountain range (Sancti Spiritu municipality, central Cuba). The 6 159ha reserve is managed by the State Department for Protection of Flora and Fauna in Banao. The Reserve has a floral richness of over 1200 species, of which a fifth is endemic or belongs to a rare, threatened or endangered category. Vegetation forms highly contrasting communities in the reserve: semideciduous forests forming vegetation complexes on "mogotes" (hills of limestone with rounded, tower-like structure) and rocky outcrops; evergreen forests and herbaceous vegetation on rocks and fissures; and mountain rain forests, where $P$. angustifolius is found. Mountain rain forests in Cuba range from 800 to 1 $800 \mathrm{~m}$ altitude, where the annual rainfall varies from 1700 to 3 000mm (Borhidi 1996). The lowest temperatures in the reserve are reached in January and February, when values range from $20.7^{\circ}$ to $21.3^{\circ} \mathrm{C}$. During July and August, temperatures reach the highest values around $25^{\circ} \mathrm{C}$. The annual average air humidity is $82 \%$, wind velocity $5.5 \mathrm{~km} / \mathrm{h}$ and the photoperiod 7.5 h/day (CITMA 2003). Moderately deep, mountain ferralitic soils are dominant in the area, accompanied by karstic outcrops. In the mountain rain forest, a dense leaf-dominated 
litter commonly accumulates on the ground. The litter retains water and, in general, avoids highly variable humidity changes in the upper centimeters of the soil.

Vegetation is structured into two welldifferentiated tree layers from $20-25 \mathrm{~m}$ and 8-19m height, supporting a rich community of epiphytes. Arborescent ferns are also abundant. The highest tree layer is dominated by microand notofilous-leaf perennial species such as Magnolia cubensis Urb., Laplacea angustifolia Britt. et Wils., Laplacea wrightii Griseb, Cyrilla racemiflora L., Ocotea cuneata (Griseb.) Urb., Ocotea floribunda (Sw.) Mez, Ocotea leucoxylon (Sw.) Mez and Myrsine coriacea (Sw.) R. Br. ex Roem. \& Schult. In the lowest tree layer, tree species such as Clusia tetrastigma Vesque, Gomidesia lindeniana Berg., Garrya fadyenii Hook, Miconia puntacta (Desv) D. Don, Alchornea latifolia Sw., Matayba domingensis (DC) Radlf., and an arborescent fern, Cyathea arborea Smith., are dominant. Hygrophilous orchids and Bromeliaceae plants mainly form the epiphyte community, and ferns are of secondary importance. In the understory, terrestrial orchids and Melastomataceae shrubs are abundant (Borhidi 1996).

$P$. angustifolius belongs to the botanical family of Podocarpaceae (Coniferopsida). It is a small tree which reaches $8 \mathrm{~m}$ in height and $30 \mathrm{~cm}$ of normal trunk diameter. Leaves are lineal-lanceolate, $4-5 \mathrm{~cm}$ wide. Microstrobili are arranged in clusters, whereas the ovules are isolated. The fruit has a red fleshy peduncle holding one $5-6 \mathrm{~mm}$ diameter elliptic seed. Seeds are recalcitrant, a trait which is well represented in Podocarpaceae (Fountain et al. 1989, Schaefer 1990). Fruit ripening occurs from January to March and seed dispersal occurs around the middle to end of April. $P$. angustifolius is endemic to mountains in the Escambray and Pinar del Río regions. Populations have undergone a recent decline due to the abusive use of P. angustifolius wood for the production of ornamental elements and hardwood devices. Recently, P. angustifolius has been classified as is in danger of extinction by the IUCN (2009), so national Cuban law has protected it.

\section{Plant nomenclature: Liogier (1962)}

Soil seed bank: We selected a stand in a well conserved mountain forest in the Ecological Reserve of Alturas de Banao containing 16 $P$. angustifolius adult individuals with apparently healthy phenotype. Distance between $P$. angustifolius tree crowns ranged from $2 \mathrm{~m}$ to $50 \mathrm{~cm}$, so branches from neighboring trees were interlaced in some cases. Eight $30 \mathrm{~cm} \mathrm{x}$ $30 \mathrm{~cm}$ plots were placed at random in the stand. In early April 2007, just a few days before the beginning of $P$. angustifolius seed dispersal, plots were excavated at $10 \mathrm{~cm}$ depth with a small garden spade and collected individually in labeled polyethylene bags, forming each one a soil sample.

In the laboratory, healthy $P$. angustifolius seeds (intact seed coat, dark color similar to that when ripened, and resistance to slight pressure with tweezers) were extracted by washing soil samples on a $0.5 \mathrm{~mm}$-mesh sieve. When extracted, four 25-seed lots were prepared at random. Seeds of each lot were placed on a distilled-water saturated filter paper sheet in a white plastic rectangular tray $(21.2 \mathrm{~cm} \mathrm{x}$ $12.2 \mathrm{~cm}$ ) and incubated in the laboratory over 2 months at $20-25^{\circ} \mathrm{C}$, which closely resembled temperature conditions in the natural habitat. Filter paper was kept wet by periodic watering.

Checks for germination started five days after the first watering. Germinated seeds were counted and removed. Seeds were considered as germinated when cotyledons emerged. The presence of fungi on seeds was also registered.

Seeds directly collected from trees: During April 2007, freshly ripened seeds were collected directly from trees, using a ladder when necessary. Seeds from different trees where combined forming a unique seed lot. After storage for two days in the laboratory, seeds were incubated following an identical protocol to that described for seeds extracted from soil samples. 
Pretreatments of seeds: One hundred seeds selected at random from both samples extracted from the soil and those directly collected from trees were submerged for $48 \mathrm{~h}$ in distilled water at room temperature $\left(20-25^{\circ} \mathrm{C}\right)$. Immediately, they were incubated under identical conditions as described above.

To analyze the germination response of $P$. angustifolius seeds, a balanced factorial design including two factors was used. Factors and levels were as follows. Seed source, with two levels: (i) seeds extracted from soil samples and (ii) freshly ripened seeds directly collected from trees. Pretreatment: (i) seed water immersion for $48 \mathrm{~h}$ and (ii) seeds non-submerged.

The effects of both factors were evaluated on two dependent variables: (i) final cumulative germination and (ii) rate of germination. The latter was computed by the formula proposed by Hartmann \& Kester (1966):

$$
\mathrm{VC}=\frac{\mathrm{SG}}{A_{1} T_{1}+A_{2} T_{2}+A_{n} T_{n}} * 100
$$

where $\mathrm{VC}$ is the coefficient of germination rate; $\mathrm{SG}$ is the number of seeds germinated; $\mathrm{A}$ is the number of germinating seeds between two consecutive times; and $\mathrm{T}$ is the time elapsed between the beginning of the germination and the interval determined as the mean.

Two-way ANOVAs were conducted with the statistical package SPSS v. 17 (2008). Prior to analysis, the value of germination (in percentage) was square-root arcsine transformed in order to improve the fit of data to the normal distribution. Significance of interactions was explored by contrasting confidence intervals.

Data of cumulative seed germination were fitted to logistic-model curves with the program Curve Expert 1.3.

\section{RESULTS}

Germination response of $P$. angustifolius seeds: Germination began about 4 weeks after incubation, both in seeds extracted from soil samples and those collected from trees, regardless of the pretreatment (Fig. 1). Final
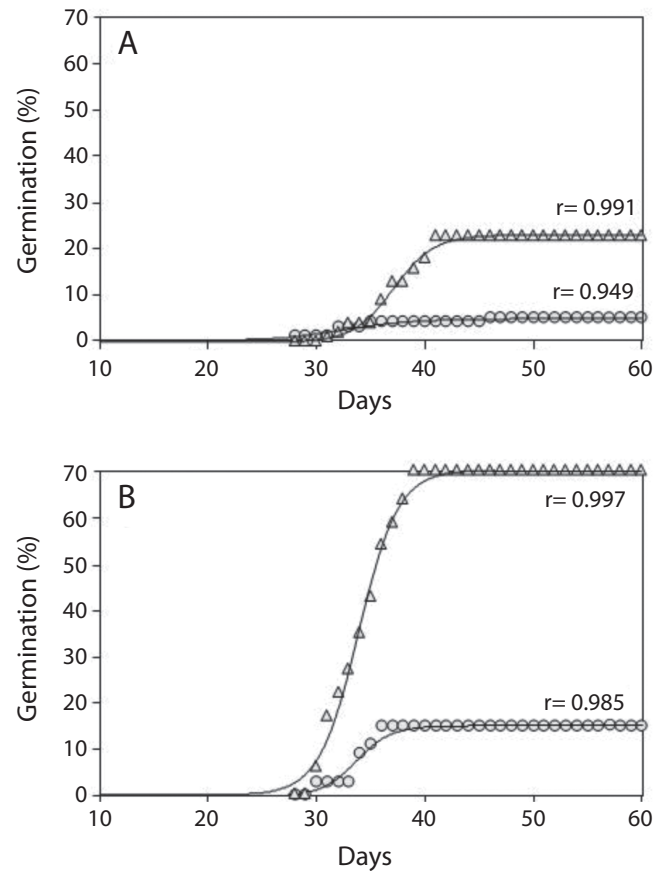

$\Delta$ Seeds from trees $O$ Seeds from the soil

Fig. 1. Cumulative germination without (A) and with (B) pretreatment (seed water-immersion for $48 \mathrm{~h}$ ) of freshly matured seeds collected directly from trees (triangles) and seeds extracted from soil samples (circles). The logistic curve adjusted ( $\mathrm{r}=$ correlation coefficient) is shown for each case.

cumulative germination was significantly affected by the two factors analyzed and their interaction (Table 1). Indeed, germination was higher in seeds collected from trees than in those from soil. Differences increased with the water-immersion seed pretreatment (Fig. 1). So, the lowest germination percentage was recorded in seeds extracted from the soil samples that were not pretreated (5\%; Fig. $1 \mathrm{~A})$, whereas the highest value was achieved by pretreated freshly matured seeds collected from trees (70\%; Fig. 1B). In addition, seeds coming from the soil, which were not exposed to water-immersion, suffered the attack of fungus Rhizopus stolonifer Ehrenb. (Ex Fr.) Lind, at the beginning of day 12 of incubation. 
TABLE 1

Two-way ANOVA for final cumulative germination and germination rate

$\begin{array}{lccc}\text { Final cumulative germination } & \mathrm{df}^{\mathrm{a}} & \mathrm{F}^{\mathrm{b}} & \mathrm{p}^{\mathrm{c}} \\ \text { Source }^{\mathrm{d}}(\mathrm{S}) & 1 & 366.19 & <0.001 \\ \text { Pretreatment }^{\mathrm{e}}(\mathrm{PT}) & 1 & 224.62 & <0.001 \\ \mathrm{~S} \text { x PT } & 1 & 60.30 & <0.001 \\ \text { Germination rate } & & & \\ \text { Source (S) } & 1 & 0.11 & 0.744 \\ \text { Pretreatment (PT) } & 1 & 22.11 & <0.001 \\ \text { S x PT } & 1 & 0.08 & 0.786\end{array}$

${ }^{\mathrm{a}}$ Degrees of freedom; ${ }^{\mathrm{b}} \mathrm{F}$ ratio value; ${ }^{\mathrm{c}}$ Associated probability; ${ }^{\mathrm{d}}$ Source: source of seeds (directly collected from trees versus retrieved from soil samples); ${ }^{\text {e }}$ Pretreatment: treatment of seed water-immersion for $48 \mathrm{~h}$ prior to seed incubation (versus no immersion pretreatment). Interaction is also shown.

Germination rate was significantly affected by the pretreatment. Seed water-immersion accelerated germination. In contrast, seed source (soil versus tree) was irrelevant for germination rate, as no significant interaction was detected (Table 1). Maximum cumulative germination (i.e., asymptote of the logisticmodel curve) without (Fig. 1A) and with (Fig. 1B) the germination pretreatment was achieved after 40 and 36-38 days, respectively.

Soil seed bank: The mean number of $P$. angustifolius seeds with healthy appearance that were extracted from soil samples was 25.50 ( $\mathrm{SE}=1.67)$, corresponding to a density (number of seeds per surface unit at a given depth) of c.a. 283 seeds $/ \mathrm{m}^{2}$. If such a value is corrected by the maximum percentage of germination recorded in the incubation of seeds extracted from the soil (15\% final cumulative germination in seeds pretreated; Fig. 1B), then we can estimate a viable seed reserve of c.a. 42 seeds $/ \mathrm{m}^{2}$ in the upper $10 \mathrm{~cm}$ of soil.

\section{DISCUSSION}

Several findings in the present study strongly suggest that $P$. angustifolius seeds have non-deep, simple morphophysiological dormancy, according to the classification proposed by Baskin \& Baskin (1998). Germination was delayed four weeks in all cases, regardless of seed source (soil seed bank versus direct seed collection from trees) and the pretreatment (water immersion versus non-immersion). Fors (1965) previously detected the same length of delay in seed germination of this species. Such a delay would be the result of the presence of a lineal underdeveloped embryo in $P$. angustifolius seeds (Osorio \& Bonilla pers. observ.), a seed trait broadly found among members of the Podocarpaceae family (Baskin \& Baskin 1998). This rudimentary embryo may need a period of 4 weeks to complete growth and reach the degree of maturation enabling it to germinate (Nikolaeva 1969, Baskin \& Baskin 1998). Moreover, the fact that seeds need nine additional days to achieve a high value of germination after it is started may suggest the existence of an additional physiological dormancy mechanism in P. angustifolius (Baskin $\&$ Baskin 1998). Our findings are in accordance with those made by $\mathrm{Ng}$ (1978) and $\mathrm{Ng}$ \& Asri (1979), who described the existence of morphological and morphophysiological dormancy in seeds of other Podocarpus species inhabiting tropical forests in Malaysia.

A noteworthy result of the study was the fact that seeds extracted from the soil immediately before the next seed dispersal event showed dormancy. Such a finding raises the following question: why did embryos of seeds at least one year old not complete their growth yet? The answer should be examined 
in the potential factor triggering the embryonic development and thus responsible for overcoming morphological dormancy. The only marked environmental difference to what seeds were exposed in the laboratory with regard to the natural habitat concerned light conditions. Actually, whereas temperature and substratum humidity did not markedly change between the soil in the natural habitat and the germination tests in the laboratory, light conditions were completely different. In the natural habitat, $P$. angustifolius seeds should be in an intensely shaded environment due to the dense canopy cover, whereas in the laboratory, seeds were directly exposed to day light during germination tests. In the literature, there are antecedents of direct exposure to light as a promoting factor of embryo growth and the subsequent break of morphophysiological dormancy (Jacobsen \& Pressman 1979, Baskin \& Baskin 1990). If this explanation is correct, this may be an efficient adaptive mechanism to detect small gaps in the canopy where seeds can germinate offering real possibilities of survival to young seedlings. Such an interpretation is compatible with field records confirming the low recruitment of $P$. angustifolius under plant cover when it is highly dense (Bonilla pers. observ.).

Other notable results in the study were the highly significant promotion of final cumulative germination and the increase of germination rate when seeds were submitted to a water-immersion pretreatment for $48 \mathrm{~h}$, particularly in the case of seeds collected from trees. Fors (1965) found a similar germination response. In some recalcitrant seeds, it has been demonstrated that the embryo requires a high level of hydration to germinate, a level superior to that in embryo tissues at the moment of seed dispersal (Tompsett 1985). In that case, abundant rainfall in the habitat is necessary to increase the germination response (Baskin \& Baskin 1998). Similar germination patterns have been registered in other recalcitrant-seeded species (Matias et al. 1973). It could be possible that the water-immersion of seeds prior to germination tests, conducted to quickly surpass the critical level of hydration, accelerated germination once dormancy was lost.

In spite of the water-immersion pretreatment, seeds extracted from soil samples showed a much lower final cumulative germination than that achieved by freshly matured seeds collected from trees (15\% versus $70 \%)$. Such a difference could be explained by the loss of viability of the former since they had been in the soil for at least one year. The factors involved in this decay of seed viability would be the attack of pathogens (indeed, a proliferation of fungus was detected during germination tests on seeds extracted from the soil and not washed by water immersion) and/or the death of the embryo by aging. However, it was surprising that $P$. angustifolius, even although recalcitrant-seeded, had a non-negligible amount of viable seeds in the soil (c.a. $42 / \mathrm{m}^{2}$ ) in early April, just before the next seed yield. This finding implies that $P$. angustifolius is able to form persistent seed banks, at least over the short-term (i.e. a fraction of seeds remain viable in the soil between two consecutive seed dispersal episodes; sensu Thompson \& Grime 1979 and Thompson et al. 1997). Studies detecting persistent seed banks in recalcitrant-seeded species are scarce in the literature ( $\mathrm{Ng} \mathrm{1988,} \mathrm{Baskin} \mathrm{\&} \mathrm{Baskin}$ 1998). Certainly, two general traits characterize recalcitrant seeds: fast germination and short periods of viability ( $\mathrm{Ng} \mathrm{1978,} \mathrm{Whitmore}$ 1989, Choinski 1990). Accordingly, it is generally assumed that recalcitrant seeds do not live for long periods in the soil, although research under natural conditions on this point is scarce (Baskin \& Baskin 1998). The notable observation that $P$. angustifolius has the ability to form persistent seed banks may be explained if their seeds are really semi-recalcitrant or minimally recalcitrant, as demonstrated for seeds of Podocarpus henkelii Stapf ex Dallim. \& A.B.Jacks. (Farrant et al. 1983); semi-recalcitrant conifer seeds which tolerate a certain degree of desiccation. Such a seed trait, along with the abundance of rainfall in the natural habitat and the preservation of soil humidity because of the dense canopy cover and the well-developed 
litter layer (Bonilla pers. observ.), may allow some seeds to be hydrated over the critical level of viability for the whole year.

Consequences of the formation of persistent soil seed banks on the plant population dynamics are important, particularly in the case of threatened species, such as P. angustifolius. A persistent seed bank can be crucial in ensuring the conservation of a species, since it allows the re-establishment and maintenance of plant populations after disturbances, although no external source of propagules occurs (Baskin \& Baskin 1978). In fact, Thompson et al. (1997) suggested that short-term persistent soil seed banks play an essential role in the viability of populations, as Martínez-Duro et al. (2010) empirically demonstrated for a critically endangered perennial plant species.

In conclusion, $P$. angustifolius seems to have seeds with morphophysiological dormancy, which may be overcome when they are directly exposed to light. This may be interpreted as an adaptive strategy to detect small gaps in the canopy where seedlings would have a higher chance of survival and establishment. The promotion of germination by water immersion of seeds induces us to consider a stimulating effect by embryo hydration. In spite of having recalcitrant seeds, $P$. angustifolius is able to form persistent seed banks in the soil, probably short-termed but essential for population viability of this endangered plant species.

\section{ACKNOWLEDGMENTS}

The authors sincerely thank José M. Herranz and Alejandro Santiago for their helpful comments on a draft version of the manuscript, and three anonymous reviewers whose corrections/suggestions substantially contributed to enhance the quality of the manuscript. This study has been done in the context of the research projects PEII10-0170-1830 (Consejería de Educación y Ciencia de la Junta de Comunidades de Castilla-La Mancha) and Montes-CSD2008-00040 (Consolider-Ingenio 2010). Kathryn Walsh checked the English.

\section{RESUMEN}

Podocarpus angustifolius es un árbol endémico de los bosques lluviosos de la región de Pinar del Río y la parte central de Cuba, que se encuentra en peligro de extinción. En este estudio se evaluó la germinación de sus semillas y la naturaleza del banco de semillas del suelo. Específicamente, se analizó la respuesta germinativa de las semillas a dos factores: su procedencia (recolectadas directamente de los árboles versus extraídas de muestras de suelo) y el pretratamiento (inmersión en agua durante $48 \mathrm{~h}$ a temperatura ambiente). La germinación no comenzó hasta las cuatro semanas ( $\approx 30$ días) en todos los casos. Además, fueron necesarios 9 días más para alcanzar un valor elevado de germinación (en el caso de semillas recolectadas del árbol con pretratamiento), lo que parece indicar la existencia de un letargo de tipo morfofisiológico simple no profundo. El pretratamiento incrementó significativamente la germinación, posiblemente por hidratación de las semillas recalcitrantes. El estudio demostró la existencia de un banco de semillas persistente en el suelo, al menos de corta duración de $\approx 42$ semillas viables por $\mathrm{m}^{2}$ en los 10 primeros $\mathrm{cm} \mathrm{del}$ suelo. Dicho hallazgo es destacable, ya que los casos descritos en la literatura sobre bancos persistentes en especies con semillas recalcitrantes son escasos. Además, se discute la importancia que tiene para esta especie amenazada la existencia de un banco de semillas persistente.

Palabras clave: planta en peligro de extinción, letargo morfofisiológico, banco de semillas del suelo persistente, tratamiento pregerminativo, semillas recalcitrantes.

\section{REFERENCES}

Baskin, C.C. \& J.M. Baskin. 1998. Seeds. Ecology, biogeography, and evolution of dormancy and germination. Academic, San Diego, California, USA.

Baskin, J.M. \& C.C. Baskin. 1978. The seed bank in a population of an endemic plant and its ecological significance. Biol. Conserv. 14: 125-130.

Baskin, J.M. \& C.C. Baskin. 1990. Seed germination ecology of poison hemlock, Conium maculatum. Can. J. Bot. 68: 2018-2024.

Borhidi, A. 1996. Phytogeography and vegetation ecology of Cuba. Akademiai Kiado, Budapest, Hungry.

Brown, A.H. \& L. Oosterhuis. 1981. The role of buried seed in coppicewoods. Biol. Conserv. 21: 19-38.

Chin, H.F., B. Krishnapillay \& P.C. Stanwood. 1989. Seed moisture: recalcitrant vs. orthodox seeds. Crop Science Society of America, Special Publication 14: 15-22. 
Choinski, J.S. 1990. Aspects of viability and post-germinative growth in seeds of the tropical tree, Trichilia dregeana Sonder. An. Bot. 66: 437-442.

Copete, M.A., J.M. Herranz \& P. Ferrandis. 2005. Seed dormancy and germination in threatened Iberian Coincya (Brassicaceae) taxa. Écoscience 12: 257-266.

Farrant, J.M. \& P. Berjak. 1983. Recalcitrance in Podocarpus henkelii. Proceedings of the Electron Microscopy Society of Southern Africa 13: 75-76.

Fors, A. 1965. Maderas Cubanas. INRA, La Habana, Cuba.

Fountain, D.W., J.M. Holdsworth \& H.A. Outred. 1989. The dispersal unit of Dacrycarpus dacrydioides (A. Rich.) de Laubenfels (Podopcarpaceae) and the significance of the fleshy receptacle. Bot. J. Lin. Soc. 99:197-207.

Hartmann, H.T. \& D. Kester. 1966. Propagación de plantas. Principios y prácticas. Edición Revolucionaria, La Habana, Cuba.

Ikeda, H. \& K. Itoh. 2001. Germination and water dispersal of seeds from a threatened plant species Penthorum chinense. Ecol. Res. 16: 99-106.

IUCN. 2009. Red list of threatened species. 2009.2 Version. (www.iucnredlist.org).

Jacobsen, J.V. \& E. Pressman. 1979. A structural study of germination in celery (Apium graveolens L.) seed with emphasis on endosperm breakdown. Planta 144: 241-248.

Liogier, H.A. 1962. Flora de Cuba. Vol. I. Asoc. de Est. de Ciencias Biológicas, Cuba.

Major, J. \& W. Pyott. 1966. Buried, viable seeds in two California bunchgrass sites and their bearing on the definition of a flora. Vegetatio 13: 253-282.

Martínez-Duro, E., P. Ferrandis, J.M. Herranz \& M.A. Copete. 2010. Do seed harvesting ants threaten the viability of a critically endangered non-myrmechorous perennial plant population? A complex interaction. Popul. Ecol. 52: 397-405.

Matias, A.R., A. Betancourt, A. Zayas, A. Pena \& R. Rivero. 1973. Forest seed in Cuba. In Seed Processing Proc. Symposium IUFRO Working Group on Seed Problems, Bergen. Vol. II, Paper 31.

Milberg, P. 1994. Germination ecology of the endangered grassland biennial Gentianella campestris. Biol. Conserv. 70: 287-290.
Navarro, L. \& J. Guitian. 2003. Seed germination and seedling survival of two threatened endemic species of the northwest Iberian Peninsula. Biol. Conserv. 109: 313-320.

Ng, F.S.P. \& N.S. Asri. 1979. Germination of fresh seeds of Malaysian trees IV. Malays. For. 42: 221-224.

Ng, F.S.P. 1978. Strategies of establishment in Malaysian forest trees, p. 129-162. In P.B. Tomlinson \& M.H. Zimmermman (eds.). Tropical trees as living systems. Cambridge University, Cambridge, United Kingdom.

Ng, F.S.P. 1988. Forest tree biology, p. 102-125. In Earl of Cranbrook (ed.). Key environments: Malaysia. Pergamon, Oxford, United Kingdom.

Nikolaeva, M.G. 1969. Physiology of deep dormancy in seeds. Izdatel'stvo "Nauka”, Leningrado, Rusia.

Nikolaeva, M.G. 1977. Factors controlling the seed dormancy pattern, p. 51-74. In A.A. Khan (ed.). The physiology and biochemestry of seed dormancy and germination. North-Holland, Amsterdam, Holanda.

Schaefer, C. 1990. Storage and germination of seeds of Podocarpus milanjianus, $\mathrm{N}^{\mathrm{o}}$ 11. Technical Note, Kenya Forestry Research Institute, Kenia.

Schafer, D.E. \& D.O. Chilcote. 1969. Factors influencing persistence and depletion in buried seed populations. I. A model for analysis of parameters of buried seed persistence and depletion. Crop Sci. 9: 417-419.

Schemske, D.W., B.C. Husband, M.H. Ruckelshaus, C. Goodwillie, I.M. Parker \& J.G. Bishop. 1994. Evaluating approaches to the conservation of rare and endangered plants. Ecol. 75: 584-606.

Simpson, R.L., M.A. Leck \& V.T. Parker. 1989. Seed banks: general concepts and methodological issues. In M.A. Leck, V.T. Thomas \& R.L. Simpson (eds.). Ecology of soil seed banks. Academic, San Diego, California, USA.

Solbrig, O.T. 1980. Demography and natural selection, p. 1-20. In O.T. Solbrig (ed.). Demography and evolution in plant populations. Botanical Monographs. Blackwell Scientific, Oxford, United Kingdom.

Thompson, K. 1992. The functional ecology of seed banks, p. 231-258. In M. Fenner (ed.). The ecology of regeneration in plant communities. C.A.B. International, Wallingford, United Kingdom.

Thompson, K., J. Bakker \& R. Bekker. 1997. The soil seed banks of North West Europe: methodology, density and longevity. Cambridge University, Cambridge, United Kingdom. 
Thompson, K. \& J.P. Grime. 1979. Seasonal variation in the soil seed banks of herbaceous species in ten contrasting habitats. J. Ecol. 67: 893-921.

Tompsett, P.B. 1985. The influence of moisture content and storage temperature on the viability of Shorea almon, Shorea robusta, and Shorea roxburghii seed. Can. J. For. Res. 15: 1074-1079.
Vázquez, C., A. Orozco, M. Rojas, M. Sánchez \& V. Cervantes. 1997. La reproducción de las plantas: semillas y meristemos. Fondo de Cultura Económica, México D.F., México.

Whitmore, T.C. 1989. Canopy gaps and the two major groups of forest trees. Ecology 70: 536-538. 